\title{
FINANCIAL RATIO RETURN ON EQUITY DENGAN NET PROFIT MARGIN SEBAGAI VARIABEL MODERATOR
}

\author{
MOELJADI \\ Fakultas Ekonomi dan Bisnis Universitas Muhammadiyah Tangerang \\ Email: moeljadi72@gmail.com
}

\begin{abstract}
Abstrak
Penelitian ini bertujuan untuk mengetahui pengaruh Analisis Pengaruh Financial Ratio (Current Ratio, Debt Equity Ratio, Total Asset Turnover, Gross Profit Margin) Terhadap Return On Equity Dengan Net Profit Margin Sebagai Variabel Moderator. Metode yang digunakan dalam penelitian ini adalah metode deskriptif dan analisis. Alat analisis menggunkan metode regresi berganda dan regresi berganda dimoderasi. Populasi dalam penelitian ini meliputi beberapa perusahaan pertambangan yang terdaftar di BEI pada tahun 2011-2014. Teknik pengambilan sampel yang digunakan dalam penelitian ini adalah metode purposive sampling dengan 12 perusahaan Pertambangan sektor batubara dan MIGAS sebagai sampel.

Pada hasil penelitian ini menunjukan bahwa secara parsial Current Ratio (CR) dan Debt Equity Ratio (DER) terhadap Return On Equity (ROE) tidak berpengaruh dan tidak signifikan. Sedangkan secara parsial Total Asset TurnOver (TATO) dan Gross Profit Margin (GPM) berpengaruh dan signifikan terhadap Return On Equity (ROE). Pada pengujian berikutnya variabel Current Ratio (CR) dan Debt Equity Ratio (DER) yang diperkuat hubunganya oleh Net Profit Margin (NPM) terhadap Return On Equity (ROE).
\end{abstract}

Kata kunci: Current Ratio (CR), Debt Equity Ratio (DER), Total Asset TurnOver (TATO), Gross Profit Margin (GPM), Net Profit Margin (NPM) dan Return On Equity (ROE).

\section{PENDAHULUAN}

Informasi kinerja keuangan diperlukan untuk menilai perubahan potensial sumber daya ekonomi, yang mungkin dikendalikan di masa depan dan untuk mempredikasi kapasitas produksi dari sumber daya yang ada (Barlian, 2003). Kinerja suatu perusahaan merupakan hasil dari serangkaian proses dengan mengorbankan berbagai sumber daya. Adapun salah satu parlementer kinerja tersebut adalah laba (Kasmir, 2010). Untuk memperoleh laba, perusahaan harus melakukan kegiatan operasional yang didukung oleh adanya sumber daya yang dimiliki. Laporan keuangan yang telah dianalisis sangat diperlukan pemimpin perusahaan atau manajemen untuk dijadikan sebagai alat pengambilan keputusan lebih lanjut untuk masa yang akan datang. Salah satu tolak ukur keberhasilan suatu perusahaan adalah kondisi keuangan perusahaan secara keseluruhan. Untuk menilai kinerja perusahaan 
dapat menggunakan analisis rasio keuangan. Rasio keuangan terdiri dari rasio likuiditas, rasio aktivitas, rasio profitabilitas dan rasio solvabilitas.

Mengingat kondisi ekonomi yang selalu mengalami perubahan, maka hal tersebut dapat mempengaruhi kondisi perusahaan yang dapat dilihat dari labanya. Laba perusahaan yang harus meningkat, justru sebaliknya mengalami penurunan. Indonesia merupakan salah satu negara yang kekayaan alamnya sangat luar biasa, beberapa diantaranya bahan tambang batubara, minyak dan gas bumi (MIGAS). Banyak hasil tambang dari Indonesia telah menjadi industri yang menunjang perekonomian Indonesia. Perusahaan pertambangan sekarang ini tetap menjadi salah satu perusahaan utama yang mengerakan perekonomian indonesia terlihat dari kontribusi penerimaan negara yang setiap tahun meningkat. Pada tahun 2012 terjadi ekspor yang tinggi mengakibatkan adanya regulasi dari pihak pemerintah yang mengeluarkan tentang larangan ekspor batubara.

Perusahaan pertambangan minyak dan gas bumi biasa yang disebut dengan MIGAS. Indonesia menduduki peringkat 25 sebagai negara dengan potensi minyak terbesar yaitu sebesar 4,3 milyar barrel, selain itu indonesia juga menduduki peringkat 21 penghasil minyak mentah terbesar dunia sebesar 1 juta barrel/ hari. Indonesia juga menduduki peringkat 24 negara pengimpor minyak terbesar sebesar 370.000/ hari, dan peringkat 22 negara pengonsumsi minyak terbesar sebesar 1 juta barrel/ hari, peringkat 13 negara dengan cadangan gas alam terbesar sebesar 92.9 trillion cubic feet, peringkat ke-8 penghasil gas alam terbesar dunia sebesar $7.2 \mathrm{tcf}$, peringkat ke-18 negara pengonsumsi gas alam terbesar sebesar $3.8 \mathrm{bcf} /$ hari, peringkat ke-2 negara pengekspor LNG terbesar sebesar 29.6 bcf,

Karena terjadinya penurunan aktifitas ekonomi global yang telah menurunkan permintaan Batubara di pasar internasional. Hal tersebut menyebabkan turunnya pendapatan perusahaan yang diikuti oleh penurunan laba bersih perusahaan dan berdampak pada kinerja keuangan perusahaan. Berdasarkan data diatas beberapa perusahaan batubara pada tahun 2011 sampai tahun 2014 sebagai berikut : 
Tabel 1. Data Return On Equity pada Perusahaan Pertambangan Batubara yang terdaftar di BEI periode 2011-2014

\begin{tabular}{cccccc}
\hline \multirow{2}{*}{ No. } & Kode & \multicolumn{5}{c}{ ROE Per Tahun $(\%)$} \\
& Perusahaan & 2011 & 2012 & 2013 & 2014 \\
\hline 1 & ADRO & 22,61 & 12,80 & 7,18 & 5,62 \\
2 & ARII & 1,94 & $(7,73)$ & $(7,99)$ & $(22,93)$ \\
3 & ATPK & $(29,62)$ & $(38,2)$ & 1,16 & 4,51 \\
4 & BRON & 5,30 & $(156,1)$ & 196,69 & - \\
5 & BRAU & 24,84 & $(74,09)$ & $(202,3)$ & 246,01 \\
6 & BSSR & 35,76 & 35,76 & 5,43 & 2,82 \\
7 & BUMI & 33,57 & $(179,9)$ & 217,89 & 63,56 \\
8 & BYAN & 29,13 & 7,76 & $(12,27)$ & $(73,97)$ \\
9 & DEWA & 0,14 & $(15,14)$ & $(23,3)$ & 0,13 \\
10 & DOID & $(16,06)$ & $(17,04)$ & $(42,93)$ & 16,83 \\
11 & GEMS & 10,62 & 6,17 & 5,73 & 4,34 \\
12 & GTBO & 0,33 & 74,2 & $(8,15)$ & $(6,72)$ \\
13 & HRUM & 50,01 & 37,72 & 12,55 & 0,72 \\
14 & ITMG & 50,53 & 43,1 & 23,91 & 22,28 \\
15 & KKGI & 68,51 & 32,18 & 23,5 & 11,08 \\
16 & MBAP & - & - & - & 20,03 \\
17 & MYOH & 19,41 & 13,34 & 22,22 & - \\
18 & PKPK & $(1,54)$ & $(5,19)$ & 0,19 & $(19,38)$ \\
19 & PTBA & 37,82 & 34,21 & 24,55 & 23,29 \\
20 & PTRO & 33,06 & 26,23 & 8,76 & 1,17 \\
21 & SMMT & 8,86 & 3,21 & 4,17 & - \\
22 & TKGA & 68,40 & - & $(39,84)$ & - \\
23 & TOBA & 190,46 & 10,76 & 31,15 & 25,15 \\
\hline & & & & &
\end{tabular}

Tabel 2. Data Return On Equity pada Perusahaan Pertambangan Minyak Dan Gas Bumi yang terdaftar di BEI periode 2011-2014

\begin{tabular}{lccccc}
\hline & \multirow{2}{*}{ Ko. } & \multicolumn{4}{c}{ ROE Per Tahun (\%) } \\
& Perusahaan & 2011 & 2012 & 2013 & 2014 \\
\hline 1. & ARTI & 1,47 & 6,06 & 7,16 & 3,11 \\
2. & BIPI & - & 0,23 & 11,63 & 5,34 \\
3. & ELSA & - & 6,64 & 10,62 & 16,19 \\
4. & ENGR & 2,83 & 3,99 & 19,53 & 1,94 \\
5. & ESSA & - & 10,07 & 13,98 & 10,29 \\
6. & MEDC & 57,11 & 2,24 & 1,79 & 1,49
\end{tabular}




\begin{tabular}{llllll} 
7. & RUIS & 1,53 & 12,19 & 11,32 & 17,94 \\
8. & SUGI & 5,65 & 1,08 & 10,62 & 1,56 \\
\hline
\end{tabular}

Sumber : Indonesia Capital Market Directory 2015 (diolah)

Berdasarkan tabel data Return On Equity I.1 dan data tabel I.2 dapat diketahui bahwa pada tahun 2011- 2014 Return On Equity yang dimiliki masing-masing perusaaan tidak stabil. Setiap tahunnya beberapa perusahaan mengalami penurunan dari tahun ke tahun bahkan, ada perusahaan yang mengalami fluktuatif maupun mengalami sedikit kenaikan. Keberhasilan kinerja keuangan suatu perusahaan dapat dilihat dari Return On Equity yang dimiliki oleh perusahaan tersebut. Selama ini telah banyak penelitian tentang Return On Equity, karena Return On Equity merupakan hal yang penting dan diperhatikan banyak pihak baik itu investor dan kreditur yang dapat mempengaruhi Return On Equity dalam menginvestasikan modalnya.

Keberhasilan kinerja keuangan perusahaan dapat diukur dari Return On Equity (Suad Husnan, 2001). Current Ratio mengukur aktiva yang dimiliki perusahaan dalam hutang lancar perusahaan. Rasio lancar bisa menunjukan sejauh mana tagihan jangka pendek yang telah jauth tempo dari kreditur dapat dipenuhi dengan aktiva yang diharapkan akan konversikan menjadi uang tunai dalam waktu yang dekat. Gap research atau kesenjangan peneliti yang terjadi tentang peneliti mengenai pengaruh Current Ratio terhadap Retrun On Equity :

Tabel 3. Pengaruh Current ratio terhadap Retrun On Equity

\begin{tabular}{ll}
\hline Penelitian & \multicolumn{1}{c}{ Peneliti } \\
\hline Berpengaruh Signifikan & Fithri Sylviana Anggraini, Farida Titik (2012); Riza Kurnia \\
& (2015); Sofia Maulida Dan Ikhwan Ashadi (2008); \\
& Aminatuzzahra (2010); Yuli Orniati (2009); Jihan Salim \\
& (2015); Nuril Maratus Sholikhah (2015) \\
Tidak Berpengaruh & Ida Nurhayati (2015); Zulfadli (2013); Qasim Saleem Dan \\
& Ramiz Ur Rehaman (2011); Debora Setiati Santosa (2009); \\
& Desi Kartikaningsih (2013)
\end{tabular}

Sumber : Penelitian Terdahulu

Debt to Equity Ratio merupakan hasil perbandingan antara total hutang yang dimiliki perusahaan dengan modalnya sendiri (Equitas). Rasio ini sering digunakan para analisis dan para investor untuk melihat seberapa besar hutang perusahaan jika dibandingkan dengan equitas yang dimiliki oleh perusahaan atau para pemegang saham. Gap research atau kesenjangan peneliti yang terjadi tentang penelitian mengenai pengaruh Debt Equity Ratio terhadap Retrun On Equity adalah :

Tabel 4. Pengaruh Debt Equity Ratio terhadap Retrun On Equity

Penelitian Peneliti

Berpengaruh Signifikan Riza Kurnia (2015); Zainal (2013); Zulfadli (2013); Buchary Jahja (2002); Aminatuzzahra (2010); Kwan Billy Kwandinata (2005); Martono,C (2002); Ena,N dan Suryana,A (2013)

Tidak Berpengaruh Henny Yulsiasti (2016); Debora Setiati Santoso (2009)

Sumber : penelitian terdahulu 
Total Asset TrunOver merupakan perputaran total aktiva digunakan untuk mengukur perputaran dari semua aset yang dimiliki perusahaan. Semakin tinggi rasio ini semakin efesien penggunaan aset dan semakin cepat pengembalian dana dalam bentu kas. Semakin tinggi Total Asset TrunOver menujukan semakin efektif perusahaan dalam menggunakan aktivanya untuk menghasilkan total penjualan bersih. Gap research atau kesenjangan peneliti yang terjadi tentang penelitian mengenai pengaruh Total Assets TrunOver terhadap Retrun On Equity:

Tabel 5. Pengaruh Total Assets TrunOver terhadap Retrun On Equity

\begin{tabular}{cl}
\hline Penelitian & \multicolumn{1}{c}{ Peneliti } \\
\hline Berpengaruh Singifikan & Fithri Sylviana Anggraini, Farida Titik (2012); Ida Nurhayati \\
& (2015); Sofia Dan Ikhwan (2008); Aminatuzzahra (2010); \\
& Kwan Billy Kwandinata (2005); Debora Setiati Santoso \\
& (2009); Desi Kartikaningsih (2013) \\
Ridak Berpengaruh & Riza Kurnia (2015); Arif Dan Shalahuddin (2012); Pieter \\
& Leununpun (2003);
\end{tabular}

Sumber : Penelitian Terdahulu

Gross Profit Margin mengukur kemampuan untuk menghasilkan laba kotor dengan penjualan yang dicapai perusahaan. Rasio Gross Profit Margin atau margin keuntungan dicari dengan penjualan bersih dikurangi harga pokok penjualan dibagi penjualan bersih. Kelemahan dari rasio ini adalah hanya menyediakan keuntungan kotor dari penjualan yang dilakukan tanpa memasukan struktur biaya yang ada pada perusahaan (Darsono, 2005). Gap research atau kesenjanga penelitian yang terjadi tenteng penelitian mengenai pengaruh Gross Profit Margin terhadap Retrun On Equity:

Tabel 6. Pengaruh Gross Profit Margin terhadap Retrun On Equity

\begin{tabular}{ll}
\hline \multicolumn{1}{c}{ Penelitian } & \multicolumn{1}{c}{ Peneliti } \\
\hline Berpengaruh Signifikan & Zulfadli (2013); Ida Nurhayati (2015); \\
Tidak Berpengaruh & Fithri Sylviana Anggraini, Farida Titik (2012); Meilia Ulfa \\
& (2015); Ramana, Azash Dan Krishnaiah (2011); \\
\hline
\end{tabular}

Sumber : penelitian terdahulu

Berdasarkan hasil review pengaruh Current Ratio, Debt Equity Ratio, Total Asset TrunOver dan Gross Profit Margin menujukan bahwa beberapa indikator merupakan hal yang penting dalam pengaruhnya terhadap Retrun On Equity. Dikuatkan dengan beberapa hasil penelitian terdahulu dan berbagai macam dugaan para ahli yang masih menujukan fenomena yang berbeda diantara empat variabel tersebut.

Dapat disimpulkan dari tabel I.3 sampai dengan tabel I.6 menujukan bahwa penelitian terdahulu tentang pengaruh Current Ratio, Debt Equity Ratio, Gross Profit Margin, dan Total Asset TrunOver terhadap Retrun On Equity. Masih menujukan adanya kesimpangsiuran antara peneliti yang satu dengan penelitian lainnya. oleh karena itu, penting untuk dilakukan penelitian kembali tentang pengaruh rasio keuangan terhadap Retrun On Equity.

\section{RUMUSAN MASALAH}

Berdasarkan latar belakang di atas, maka rumusan masalah yang akan di bahas pada penelitian ini adalah sebagai berikut yaitu : 
1. Bagaimana pengaruh Current Ratio terhadap terhadap Return On Equity

2. Bagaimana pengaruh Debt Equity Ratio terhadap Return On Equity

3. Bagaimana pengaruh Total Asset TrunOver terhadap Return On Equity

4. Bagaimana pengaruh Gross Profit Margin terhadap Return On Equity

5. Bagaimana pengaruh Net Profit Margin sebagai variable moderating dalam memperkuat atau memperlemah Current Ratio, Debt Equity Ratio, Total Asset TurnOver dan Gross Profit Margin dengan Return On Equity.

\section{TUJUAN PENELITIAN}

Berdasarkan rumusan dan batasan masalah di atas, maka dapat ditarik beberapa tujuan penelitian yang disajikan di bawah ini, yaitu :

1. Untuk mengetahui pengaruh Current Ratio terhadap terhadap Return On Equity

2. Untuk mengetahui pengaruh Debt Equity Ratio terhadap Return On Equity

3. Untuk mengetahui pengaruh Total Asset TrunOver terhadap Return On Equity

4. Untuk mengetahui pengaruh Gross Profit Margin terhadap Return On Equity

5. Untuk mengetahui pengaruh Net Profit Margin sebagai variable moderator dalam memperkuat atau memperlemah Current Ratio, Debt Equity Ratio, Total Asset TurnOver dan Gross Profit Margin dengan Return On Equity.

\section{KAJIAN PUSTAKA}

\section{Kinerja Keuangan}

Kinerja dalam organisasi merupakan jawaban dari berhasil atau tidaknya tujuan organisasi yang telah diterapkan. Para atasan atau manajer sering tidak memperhatikan kecuali sudah amat buruk atau segala sesuatu jadi serba salah. Terlalu sering manajer tidak mengetahui betapa buruknya kinerja telah merosot sehingga perusahaan atau instansi menghadapi krisis yang serius. Kesan-kesan buruk organisasi yang mendalam berakibat dan menghabiskan tanda-tanda peringatan adanya kinerja yang menyorot. Kinerja merupakan suatu kondisi yang harus kondisi yang harus diketahui dan dikonfirmasikan kepada pihak tertentu untuk mengetahui tingkat pencapaian hasil suatu instansi dihubungkan dengan visi yang diemban suatu organisasi atau perusahaan serta mengetahui dampak positif dan negatif dari suatu kebijakan operasional.

\section{Laporan Keuangan}

Menurut Tandelilin (2001) laporan keuangan merupakan informasi akuntansi yang mengambarkan seberapa besar kekayaan perusahaan, seberapa besar penghasilan perusahaan yang diperoleh perusahaan serta transaksi-trasnsaksi ekonomi apa saja yang telah dilakukan perusahaan yang bisa mempengaruhi penghasilan perusahaan. Laporan perusahaan pada dasarnya adalah hasil dari proses akuntansi yang dapat digunakan sebagai alat untuk berkomunikasi antara data keuangan atau aktivitas suatu perusahaan dengan pihak-pihak yang berkepentingan dengan data atau aktivitas perusahaan tersebut (Munawir, 2001).

\section{Analisis Rasio Keuangan}

Rasio mengambarkan suatu hubungan atau perimbangan (mathematical relationship) antara suatu jumlah tertentu dengan jumlah yang lain, dan dengan menggunakan alat analisa berupa ratio ini akan dapat menjelaskan atau memberi gambaran kepada 
penganalisa tentang baik buruknya keadaan atau posisi keuangan suatu perusahaan terutama apabila angka ratio tersebut diperbandingkan dengan angka ratio perbandingan yang digunakan sebagai standar (Munawir, 2001).

Analisis rasio keuangan adalah suatu usaha untuk mengetahui kinerja dari perusahaan yang dalam hal ini akan bermanfaat untuk mengetahui perkembangan keuangan perusahaan dan dapat diketahui hasil-hasil keuangan yang telah dicapai masa lalu. Implementasinya terhadap perusahaan adalah perusahaan akan tahu tentang perkembangan keuangan perusahaan, dan di masa yang akan datang bermanfaat untuk merencanakan langkah dimasa yang akan datang. Dengan menggunakan analisis rasio keuangan maka dapat diketahui kelemahan-kelemahan tersebut, serta akan dapat diketahui pula hasil-hasil yang telah dicapai oleh perusahaan selama ini. Hasil analisa akan sangat penting artinya bagi perbaikan penyusunan rencana yang akan datang dan kelemahan tersebut dapat diperbaiki. Dalam mengadakan interprestasi dan analisis laporan keuangan suatu perusahaan perlu adanya suatu alat analisa yaitu rasio.

\section{Return On Equity}

Profitabilitas menurut Sofyan (2007) adalah menggambarkan kemampuan perusahaan mendapatkan laba melalui semua kemampuan, dan sumber yang ada seperti kegiatan penjualan, kas, modal, jumlah karyawan, jumlah cabang, dan sebagainya. Rasio profitabilitas yang menggambarkan kemampuan perusahaan mengahasilkan laba dapat disebut juga Operating Ratio. Keuntungan yang akan diraih dari investasi yang akan ditanamkan merupakan pertimbangan utama bagi sebuah perusahaan dalam rangka pengembangan bisnisnya. Besarnya ROE sangat dipengaruhi oleh besarnya laba yang diperoleh perusahaan, semakin tinggi laba yang diperoleh maka akan semakin meningkatkan ROE. Sedangkan ROE merupakan rasio antara laba sesudah pajak terhadap total modal sendiri (ekuitas) yang berasal dari seroran pemilik, laba tidak dibagi dan cadangan lain yang dimiliki oleh perusahaan. Return on Equity dapat dirumuskan sebagai berikut :

\section{Jenis-Jenis Rasio}

$$
\text { Return On Equity }=\frac{\text { Laba Bersih Setelah Pajak }}{\text { Total Modal Sendiri }} \times 100 \%
$$

1. Rasio Likuiditas

Merupakan rasio yang mengukur kemampuan suatu perusahaan dalam memenuhi kewajiban jangka pendeknya. Dimana kreditor jangka pendek lebih memperhatikan prospek perusahaan dalam membayar kewajiban jangka pendek dengan kata lain kreditor lebih tertarik terhadap likuiditas perusahaan (Prastowo, 2002). Rasio likuiditas terdiri dari beberapa rasio, yaitu :

\section{a. Current Ratio (Rasio Lancar)}

Current ratio digunakan untuk mengukur solvency jangka pendek Rasio lancar untuk perusahaan yang normal berkisar pada angka 2, meskipun tidak ada standar pasti untuk penentuan rasio lancar yang seharusnya (Hanafi dan Abdul Halim, 2007). Berikut rumus Current ratio:

b. Quick Ratio (Rasio Cepat)

$$
\text { Current Ratio }=\frac{\text { Aktiva Lancar }}{\text { Hutang Lancar }} \times 100 \%
$$


Dengan quick ratio tidak mengambil current asset seluruhnya dalam membandingkan dengan current liabilitas (hutang lancar), melainkan kita hanya mengambil beberapa elemen di aktiva lancar yaitu yang mempunyai tingkat likuiditas tinggi seperti kas, efek, piutang. Berikut rumus Quick ratio:

\section{c. Cash Ratio (Rasio Kas)}

$$
\text { Quick Ratio }=\frac{\text { Aktiva Lancar }- \text { Persediaan }}{\text { Hutang Lancar }} \times 100 \%
$$

Cash ratio merupakan menujukan kemampuan kas perusahaan untuk melunasi hutang-hutang lancarnya tanpa harus mengubah aktiva lancar bukan kas (piutang dagang dan persediaan) menjadi kas terlebih dahulu. Berikut rumus Cash ratio :

\section{Leverage}

$$
\text { Cash Ratio }=\frac{\text { Kas }}{\text { Hutang Lancar }} \times 100 \%
$$

Maksud dari rasio ini untuk mengukur kemampuan perusahaan untuk memenuhi semua kewajiban baik jangka pendek maupun jangka panjang apabila perusahaan tersebut dilikuidasi (Munawir, 2002). Dimana kreditor jangka panjang lebih memperhatikan prospek perusahaan dalam membayar kewajiban jangka panjang dengan kata lain kreditor lebih tertarik pada solvabilitas perusahaan (Prasworo, 2002). Perusahaan yang tidak solvabel adalah perusahaan yang total hutangnya lebih besar dibandingkan dengan total asetnya (Hanafi dan Halim, 2007). Rasio solvabilitas terdiri dari beberapa rasio, yaitu :

a. Debt Asset Ratio (Rasio kewajiban atas aktivitas)

Para kreditur menginginkan rasio yang rendah karena semakin tinggi rasio ini maka semakin besar resiko yang ditanggung oleh kreditur. Semakin besar rasio ini berarti semakin besar pembelian asset dengan menggunakan hutang (Hanafi dan Abdul Halim, 2007). Berikut rumus Debt Asset Ratio:

b. Debt Equity Ratio (Rasio kewajiban atas equitas)

$$
\text { Debt Asset Ratio }=\frac{\text { Total Hutang }}{\text { Total Aktiva }} \times 100 \%
$$

Semakin tinggi Debt Equity Ratio menunjukan semakin tinggi komposisi utang perusahaan dibandingkan dengan modal sendiri sehingga berdampak besar pada beban perusahaan terhadap pihak luar karena akan meningkatkan solvabilitas perusahaan. Berikut rumus Debt Equity Ratio :

\section{c. Rasio Time Interest Earned}

$$
\text { Debt Equity Ratio }=\frac{\text { Total Hutang }}{\text { Modal Sendiri }} \times 100 \%
$$

Rasio ini digunakan untuk mengukur kemampuan operasi perusahaan dalam memberikan proteksi kepada kreditor jangka panjang, khususnya dalam membayar bunga (kemampuan membayar hutang dengan laba sebelum bunga).

\section{Aktivitas}

$$
\text { Time Interest Earned }=\frac{\text { Laba Sebelum Bunga Dan Pajak (EBIT) }}{\text { Bunga }}
$$

Rasio aktivitas merupakan rasio yang digunakan untuk mengukur efektif tidaknya perusahaan didalam menggunakan dan mengendalikan sumber yang dimiliki oleh 
perusahaan (Halim, 2004). Rasio yang digambarkan pendayagunaan harta atau sarana modal yang dimiliki oleh perusahaan atau dengan kata lain rasio ini bertujuan untuk mengukur efektifitas perusahaan dalam mengoperasikan dana yang dimilikinya. Rasio ini terdiri dari beberapa rasio, yaitu (Hanafi dan Halim, 2007) :

a. Rata-rata pencairan/ umur piutang

a) Account Receivable TrunOver (Perputaran Piutang)

Rasio ini menujukan berapa kali piutang usaha dapat berputas dalam setahun. Berikut rumus Account Receivable Trun Over:

$$
\text { Account Receivable TurnOver }=\frac{\text { Penjualan Bersih }}{\text { Piutang Bersih }}
$$

b) Account Receivable In Days Avarage Collection Period (Rata-Rata Umur Piutang)

Rasio ini menujukan beberapa lama piutang usaha dapat tertagih atau dengan kata lain, rasio ini menujukan lamanya waktu yang dibutuhkan oleh perusahaan untuk mengubah piutang menjadi uang tunai. Berikut ratarata umur piutang :

$$
\text { Rata-Rata Umur Piutang }=\frac{365}{\text { perputaran Piutang }}
$$

b. Inventory TurnOver (Rasio Perputaran Persediaan)

a) Inventory TurnOver (Perputaran Persediaan)

Rasio ini menujukan berapa kali persediaan dapat berputar dalam setahun. Semkain tinggi perputaran persediaan, semkain cepat dana yang tertanam dalam persediaan berputar kembali menjadi kas. Rasio ini menujukan berapa kali persediaan berputar kembali menjadi kas. Berikut rumus Inventory TurnOver:

$$
\text { Inventory TurnOver }=\frac{\text { Harga Pokok Penjualan }}{\text { Rata-rata Persediaan }}
$$

b) Inventory Day In Hand (Rata - Rata Umur Persediaan)

Rasio ini menujukan berapa lamanya persediaan disimpan sebelum dijual. Berikut rumus Inventory Day In Hand:

$$
\text { Inventory Day In Hand }=\frac{360}{\text { Inventory TurnOver }}
$$

c) Net Fixed Asset TurnOver (Perputaran Aktiva Tetap)

Rasio ini digunakan untuk mengukur sejauh mana kemampuan perusahaan menghasilkan penjualan berdasarkan aktiva tetap yang dimiliki oleh perusahaan. Semakin tinggi rasio ini berarti semakin efektif penggunaan aktiva tetap tersebut. Berikut rumus Perputaran Aktiva Tetap :

$$
\text { Net Fixed Asset TurnOver }=\frac{\text { Penjualan Bersih }}{\text { Total Aktiva Tetap (NET) }}
$$

d) Total Assets TurnOver (Perputaran Total Aktiva)

Rasio ini mengukur sejauh mana kemampuan perusahaan menghasilkan penjualan berdasarkan jumlah aktiva yang dimilikinya. Semakin besar rasio ini maka semakin bagus hasilnya karena rasio ini menujukan kemampuan perusahaan dalam mengelolah aset. Berikut rumus Total Assets TurnOver:

$$
\text { Total Asset TurnOver }=\frac{\text { Pejualan Bersih }}{\text { Total Aktiva }}
$$




\section{Profitasbilitas}

Rasio profitabilitas merupakan rasio yang mengukur kemampuan perusahaan dalam menghasilkan keuntungan (Profitabilitas) pada tingkat penjualan aset dan modal saham tertentu (Hanafi dan Halim, 2007). Dalam rasio profitabilitas ini sudah mencangkup rasio hutang, aktivitas maupun likuiditas (Brigham, 2001). Rasio ini terdiri dari beberapa rasio, yaitu (Hanafi dan Halim, 2007) :

a. Gross Profit Margin

Rasio ini digunakan untuk mengukur efisiensi produksi dan penentuan harga jual. Rasio ini menujukan seberapa besar keuntungan kotor yang diperoleh dari penjualan produk. Berikut rumus Gross Profit Margin :

$$
\text { Gross Profit Margin }=\frac{\text { Penjualan Bersih }- \text { Harga Pokok Penjualan }}{\text { Penjualan Bersih }} \times 100 \%
$$

\section{b. Net Profit Margin}

Rasio ini menujukan sejauh mana kemampuan perusahaan menghasilkan laba bersih pada tingkat penjualan tertentu. Rasio ini menujukan berapa besar keuntungan bersih yang diperoleh. Berikut rumus Net Profit Margin :

\section{c. Return On Asset atau Return On Investement}

$$
\text { Net Profit Margin }=\frac{\text { Laba Bersih Setelah Pajak }}{\text { Penjualan Bersih }} \times 100 \%
$$

Rasio ini mengukur tingkat pengembalian dari bisnis atas seluruh aset yang ada, atau rasio ini menggambarkan efesiensi pada dana yang digunakan dalam perusahaan. Oleh karena itu rasio ini sering disebut Return On Investemen. Berikut rumus ROI :

$$
\text { Return On Investment }=\frac{\text { Laba Bersih Setelah Pajak }}{\text { Total Aktiva }} \times 100 \%
$$

d. Return On Equity atau rentabilitas modal sendiri

Rasio ini mengukur tingkat pengembalian dari bisnis atas seluruh modal yang ada. Return On Equity merupakan salah satu indikator yang digunakan oleh pemegang saham untuk mengukur keberhasilan bisnis yang dijalani. Rasio ini juga dapat disebut dengan istilah rentabilitas modal sendiri. berikut rumus Return On Equity :

$$
\text { Return On Equity }=\frac{\text { Laba Bersih Setelah Pajak }}{\text { Total Modal Sendiri }} \times 100 \%
$$

\section{Rasio pasar}

Rasio pasar merupakan rasio yang mengukur harga pasar relatif terhadap nilai buku. Sudut pandang rasio ini lebih banyak berdasarkan pada sudut investor (calon investor). Rasio ini terdiri dari beberapa rasio, yaitu (Hanafi dan Halim, 2007) :

a. Price Earning Ratio (PER)

Perusahaan yang diharapkan akan tumbuh tinggi (mempunyai prospek baik) mempunyai PER yang tinggi, sebaliknya perusahaan yang diharapkan mempunyai pertumbuhan yang rendah akan mempunyai PER yang rendah. Dari segi investor, PER yang terlalu tinggi tidak menarik karena harga saham kemungkinan tidak akan naik lagi, sehingga capital gain yang diperoleh akan lebih kecil. Berikut rumus PER :

$$
\text { Price Earning Ratio }=\frac{\text { Harga Pasar Per Lembar }}{\text { Earning Per Lembar }}
$$




\section{b. Deviden Yield}

Dari segi investor, rasio ini cukup berarti karena deviden yield merupakan sebagian dari total return yang akan diperoleh investor. Bagian Return yang lain adalah capital gain, yang diperoleh dari selisih positif antara harga jual dan harga beli. Apabila selisih negatif yang diperoleh, maka terjadi capital loss. Berikut rumus Deviden Yield :

$$
\text { Deviden yield }=\frac{\text { Deviden Per Lembar }}{\text { Harga Pasar Saham Per Lembar Saham }}
$$

c. Pembayaran deviden

Rasio ini merupakan rasio yang digunakan untuk melihat bagian earning (Pendapatan) yang dibayarkan sebagai deviden kepada investor. Bagian lain yang tidak dibagikan akan diinvestasikan kembali ke perusahaan. Berikut rumus pembayaran deviden :

$$
\text { Pembayaran Deviden }=\frac{\text { Deviden Per Lembar }}{\text { Earning Per Lembar Saham }}
$$

\section{KERANGKA BERPIKIR}

Berdasarkan latar belakang permasalahan, perumusan masalah, tujuan penelitian dan landasan teori yang dikemukakan di atas maka kerangka pemikiran teoritis yang menyatakan bahwa Current Ratio, Debt Equity Ratio, Total Asset TurnOver, Gross Profit Margin dan Net Profit Margin mempunyai pengaruh terhadap Return On Equity. Berikut kerangka pemikiran teori dari penelitian ini :

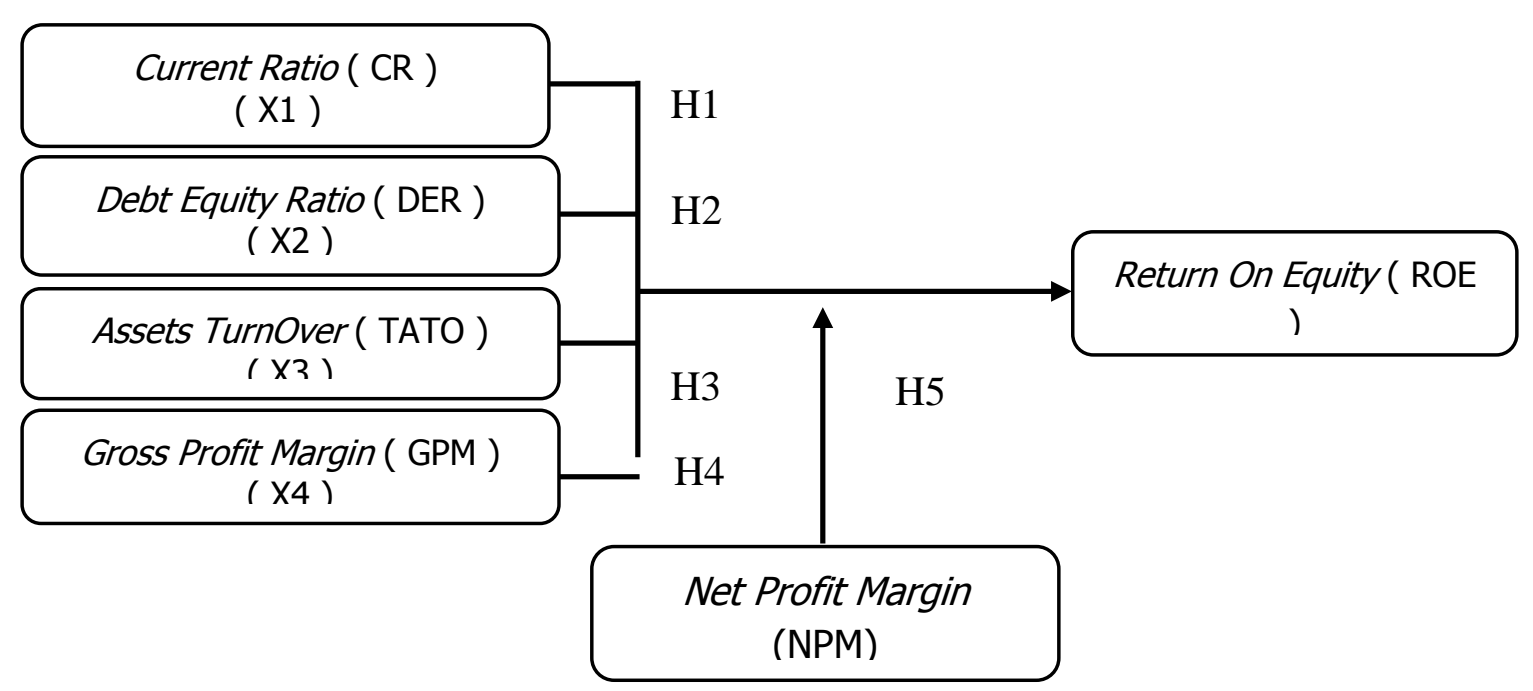

Gambar 1. Kerangka Pikir Penelitian

\section{PENGEMBANGAN HIPOTESIS}

Berdasarkan hubungan antara landasan teori terhadap rumusan masalah maka hipotesis atau dugaan sementara dari permasalahan penelitian ini adalah sebagai berikut:

$\mathrm{H}_{1}$ : Current Ratio memiliki pengaruh dan signifikan terhadap Return On Equity

$\mathrm{H}_{2}$ : Debt Equity Ratio memiliki pengaruh signifikan terhadap Return On Equity

$\mathrm{H}_{3}$ : Total Asset TurnOver memiliki pengaruh signifikan terhadap Return On Equity 
$\mathrm{H}_{4}$ : Gross Profit Margin memiliki pengaruh dan signifikan terhadap Return On Equity

$\mathrm{H}_{5}$ : Net Profit Margin memoderator hubungan CR, DER, TATO, dan GPM terhadap Return On Equity

\section{METODELOGI PENELITIAN}

Populasi dan Sampel

Populasi dalam penelitian ini adalah seluruh sub sektor pertambangan Batubara dan MIGAS yang go public di BEI selama periode 2011-2014 yaitu sebanyak 31 perusahaan. Teknik pengambilan sample yang digunakan penelitian ini adalah purposive sampling, dimana peneliti memiliki kriteria atau tujuan tertentu terhadap sampel yang akan diteliti (Indriantoro, 1999). Sample penelitian diambil secara purposive sampling, dimana sampel harus memenuhi kriteria sebagai berikut :

1. Perusahaan sub sektor pertambangan Batubara dan MIGAS yang telah selalu menyajikan laporan keuangan tahun buku berakhir 31 Desember selama periode pengamatan 2011-2014 yang terdapat di ICMD.

2. Perusahaan harus sudah listing pada awal periode pengamatan dan tidak di delisting sampai akhir periode pengamatan.

3. Dalam laporan keuangan yang mencantumkan nilai rasio keuangan yang akan diteliti meliputi Return On Equity, Current Ratio, Debt Equity Ratio, Total Asset TurnOver, Gross Profit Margin dan Net Profit Margin.

Setelah menentukan kriteria sampel perusahaan, maka perusahaan yang memenuhi kriteria adalah sebanyak 12 perusahaan pertambangan batu bara dan minyak dan gas bumi. Perusahaan-perusahaan tersebut yang menjadi sampel dalam penelitian ini ditunjukan pada tabel 3 sebagai berikut :

Tabel 3. Sampel Perusahaan

\begin{tabular}{ccl}
\hline No. & Kode Perusahaan & \multicolumn{1}{c}{ Nama Perusahaan } \\
\hline 1. & ADRO & PT. Adaro Energy, Tbk. \\
2. & GEMS & PT. Golden Energy Mines, Tbk. \\
3. & HRUM & PT. Harum Energy, Tbk. \\
4. & ITMG & PT. Indo Tambangraya Megah, Tbk. \\
5. & KKGI & PT. Resource Alam Indonesia, Tbk. \\
6. & PTBA & PT. Tambang Batubara Bukit Asam (persero), Tbk. \\
7. & PTRO & PT. Petrosea, Tbk \\
8. & TOBA & PT. Toba Bara Sejahtera, Tbk. \\
9. & ARTI & PT. Ratu Prabu Energi, Tbk \\
10. & ENRG & PT. Energi Mega Persada, Tbk. \\
11. & MEDC & PT. Medco Energi Internasiona, Tbk. (S) \\
12. & RUIS & PT. Radiant Utama Interinsco, Tbk. \\
\hline
\end{tabular}

Sumber : ICMD dan IDX 2011-2014 


\section{VARIABEL PENELITIAN DAN DEFINISI OPERASIONAL}

1. Variabel Dependen

Variabel dependen yaitu Return On Equity dalam penelitian ini variabel yang terkait oleh variabel lain. Return On Equity merupakan salah satu indikator yang digunakan oleh pemegang saham untuk mengukur keberhasilan bisnis yang dijalani. berikut rumus Return On Equity:

2. Variabel Independen

$$
\text { Return On Equity }=\frac{\text { Laba Bersih Setelah Pajak }}{\text { Total Modal Sendiri }} \times 100 \%
$$

Variabel independen sebagai variabel $\mathrm{X}$ dalam penelitian ini adalah Current Ratio, Debt To Equity Ratio, Total Assets Turnover, Gross Profit Margin.

a. Current ratio

Current ratio juga bisa digunakan untuk mengukur solvency jangka pendek Rasio lancar untuk perusahaan yang normal berkisar pada angka 2, meskipun tidak ada standar pasti untuk penentuan rasio lancar yang seharusnya (Hanafi dan Abdul Halim, 2007). Berikut rumus Current ratio:

b. Debt Equity Ratio

$$
\text { Current Ratio }=\frac{\text { Aktiva Lancar }}{\text { Hutang Lancar }} \times 100 \%
$$

Debt Equity Ratio merupakan perhitungan leverage sederhana yang membandingkan total utang yang dimiliki perusahaan dengan total ekuitas dalam menanggung risiko. Semakin tinggi Debt Equity Ratio menunjukan semakin tinggi komposisi utang perusahaan dibandingkan dengan modal sendiri sehingga berdampak besar pada beban perusahaan terhadap pihak luar karena akan meningkatkan solvabilitas perusahaan. Berikut rumus Debt Equity Ratio :

c. Total Asset Turnover

$$
\text { Total Debt Equity Ratio }=\frac{\text { Total Hutang }}{\text { Modal Sendiri }} \times 100 \%
$$

Rasio ini mengukur kemampuan perusahaan menghasilkan penjualan berdasarkan jumlah aktiva yang dimilikinya. Semakin besar rasio ini maka semakin bagus hasilnya karena rasio ini menujukan kemampuan perusahaan dalam mengelolah aset. Berikut rumus Total Assets TurnOver:

d. Gross Profit Margin

$$
\text { Total Asset TurnOver }=\frac{\text { Pejualan Bersih }}{\text { Total Aktiva }}
$$

Rasio ini digunakan untuk mengukur efisiensi produksi dan penentuan harga jual. Rasio ini menujukan seberapa besar keuntungan kotor yang diperoleh dari penjualan produk. Berikut rumus Gross Profit Margin :

3. Variabel Moderating

$$
\text { Gross Profit Margin }=\frac{\text { Penjualan Bersih }- \text { Harga Pokok Penjualan }}{\text { Penjualan Bersih }} \times 100 \%
$$

Variabel moderating adalah variabel yang memperkuat atau Memperlemah hubungan antara variabel independen dan variabel dependen. Variabel daam penelitian ini adalah Net Profit Margin. Net Profit Margin menujukan sejauh mana kemampuan perusahaan menghasilkan laba bersih pada tingkat penjualan tertentu. Rasio ini 
menujukan berapa besar keuntungan bersih yang diperoleh. Berikut rumus Net Pofit Margin :

$$
\text { Gross Profit Margin }=\frac{\text { Penjualan Bersih }- \text { Harga Pokok Penjualan }}{\text { Penjualan Bersih }} \times 100 \%
$$

\section{DEFENISI OPERASIONAL}

Tabel 4. Definisi Operasional

\begin{tabular}{|c|c|c|c|c|}
\hline No & Variabel & Definisi & Simbol & Pengukuran \\
\hline 1 & Profitabilitas & $\begin{array}{l}\text { Rasio antara laba bersih } \\
\text { setelah pajak dengan } \\
\text { total modal sendiri }\end{array}$ & $\begin{array}{l}\text { ROE } \\
(Y)\end{array}$ & $\frac{\text { laba bersih setelah pajak }}{\text { total modal sendiri }}$ \\
\hline 2 & Likuiditas & $\begin{array}{l}\text { Rasio antara aktiva lancar } \\
\text { dengan hutang lancar }\end{array}$ & $\begin{array}{l}\text { CR } \\
(X 1)\end{array}$ & $\frac{\text { Aktiva lancar }}{\text { Hutang Lancar }}$ \\
\hline 3 & Laverage & $\begin{array}{c}\text { Rasio antara modal } \\
\text { sendiri dengan total } \\
\text { hutang }\end{array}$ & $\begin{array}{l}\text { DER } \\
(X 2)\end{array}$ & $\frac{\text { modal sendiri }}{\text { total hutang }}$ \\
\hline 4 & Aktivitas & $\begin{array}{c}\text { Rasio antara penjual } \\
\text { bersih dengan total aktiva }\end{array}$ & $\begin{array}{l}\text { TATO } \\
(\mathrm{X} 3)\end{array}$ & $\frac{\text { penjualan bersih }}{\text { total aktiva }}$ \\
\hline 5. & Profitabilitas & $\begin{array}{l}\text { Rasio antara penjualan } \\
\text { bersih dikurangi harga } \\
\text { pokok penjualan dengan } \\
\text { penjualan bersih }\end{array}$ & $\begin{array}{l}\text { GPM } \\
(X 4)\end{array}$ & $\frac{\text { penjualan bersih - HPP }}{\text { penjualan bersih }}$ \\
\hline 6. & Profitabilitas & $\begin{array}{l}\text { Rasio antara laba bersih } \\
\text { setelah pajak dengan } \\
\text { penjualan bersih }\end{array}$ & $\begin{array}{l}\text { NPM } \\
(\mathrm{M})\end{array}$ & $\frac{\text { laba bersih setelah pajak }}{\text { penjualan bersih }}$ \\
\hline
\end{tabular}

\section{JENIS DAN SUMBER DATA}

a. Jenis Data

Data numerik yang dapat memberikan penafsiran yang kokoh atau dengan kata lain, data ini berupa angka-angka yang diperoleh dari ICMD (Indonesia Capital Market Directory). Data yang diperoleh dalam bentuk informasi, baik secara lisan maupun tulisan dam digunakan untuk mendukung data lainnya.

b. Sumber Data

Sumber data yang digunakan dalam penelitian ini adalah data sekunder meliputi rata-rata Return On Equity sub sektor pertambangan batu bara dan migas yang listing di BEI, Current Ratio, Debt to Equity Ratio, Total Asset TurnOver, Gross Profit Margin dan Net Profit Margin yang dipublikasikan periode tahun 2011-2014 yang dikutip dari situs resmi idx (www.idx.com) data tersebut berupa tahunan.

\section{TEKNIK PENGUMPULAN DATA}

Data dikumpulkan dengan menggunakan metode studi pustaka. Metode studi pustaka yaitu metode yang digunakan dengan memahami literature-literaure yang membuat 
pembahasan yang berkaitan dengan melakukan klarifikasi dan kategori bahan-bahan tertulis yang berhubungan dengan masalah peneliti dengan mempelajari dokumen atau data yang diperlukan, dilanjutkan dengan pencatatan dan perhitungan. Sesuai dengan data yang diperlukan yaitu data sekunder, maka metode pengumpulan data dalam penelitian ini adalah dengan menggunakan teknik dokumentasi yang berdasarkan laporan keuangan periode 2011 - 2014 yang dipublikasikan oleh BEI melalui ICMD tahun 2014 dan download di internet (www.idx.com), mengambil dari artikel, jurnal penelitian terdahulu, mempelajari buku-buku pustaka yang mendukung penelitian terdahulu dan proses penelitian. Data yang diperlukan yaitu Return On Equity, Current Ratio, Debt Equity Ratio, Total Asset TurnOver, Gross Profit Margin, Net Profit Margin. Adapun pengolahan data dalam penelitian dengan menggunakan SPSS 15.

\section{METODE ANALISIS DATA}

Metode analisis data merupakan metode yang akan digunakan untuk mengetahui kesimpulan yang akan diperoleh dari hasil penelitian. Untuk memberikan gambaran mengenai variabel-variabel yang ada dalam penelitian, dilakukan Analisis Statistik Deskriptif. Setelah itu dilakukan Uji Asumsi Klasik untuk menganalisis apakah model penelitian sudah memenuhi asumsi klasik yang harus dipenuhi sebelum melakukan analisis regresi. Setelah asumsi klasik terpenuhi, langkah selanjutnya adalah melakukan uji Moderated Multiple Regression (MMR) untuk menguji apakah variabel moderator dapat memperkuat antara variabel-variabel independen terhadap variabel dependen. Langkah selanjutnya adalah melakukan Uji Goodness of Fit dari model dalam penelitian untuk menilai ketepatan fungsi regresi sampel dalam menilai nilai aktual. Uji ini meliputi Uji Koefisien Determinasi $\left(R^{2}\right)$ dan uji Signifikansi Simultan (Uji Statistik F). Setelah model dinyatakan fit, barulah dilakukan Uji Signifikansi Parameter Individual (Uji Statistik-t) untuk menguji hipotesis penelitian.

a. Analisis Statistik Deskriptif

Analisis statistik deskriptif akan menjelaskan mengenai data-data statistik yang berkaitan dengan mean, standar deviasi, nilai maksimum dan nilai minimum dari masing-masing variabel, yaitu CR, DER, TATO, GPM, NPM dan Return On Equity. Pengujian statistik deskriptif ini menggunakan software Statistical Package for Social Science (SPSS) versi 15.

b. Pengujian Asumsi Klasik

Uji asumsi klasik merupakan prasyarat analisis regresi berganda. Sebelum melakukan pengujian asumsi klasik meliputi : uji normalitas, uji multikolinieritas, uji autokorelasi dan uji heterosdastisitas.

a) Uji Normalitas

Menurut Ghozali (2009) menyatakan bahwa uji normalitas adalah untuk menguji apakah dalam model regresi,variabel independen dan variabel dependennya memiliki distribusi normal atau tidak. Model regresi yang baik adalah memiliki distribusi data normal atau mendekati normal. Pada prinsipnyanormalitas data dapat diketahui dengan melihat penyebaran data (titik) pada sumbu diagonal pada grafik atau histogram dari residualnya. Data normal dan tidak normal dapat diuraikan sebagai berikut (Ghozali, 2009); 
1. Jika data menyebar di sekitar garis diagonal dan mengikuti arah garis diagonal atau grafik histogramnya, menunjukkan pola terdistribusi normal, maka model regresi memenuhi asumsi normalitas.

2. Jika data menyebar jauh dari garis diagonal dan tidak mengikuti arah garis diagonal atau grafk histogramnya, tidak menunjukkan pola terdistribusi normal, maka model regresi tidak memenuhi asumsi normalitas.

Selain melihat pada sumbu diagonal pada grafik atau histogram dari residualnya. Uji normalitas juga bisa dilakukan dengan menggunakan nilai statistik model kolmogrof smirnov. Dimana data dikatakan normal apabila nilai Asym. Sg lebih besar dari 0,05.

b) Uji Multikolinieritas

Uji multikolinieritas bertujuan untuk menguji apakah model regresi ditemukan adanya korelasi antara variabel bebas (independent variable). Model regresi yang baik seharusnya tidak terjadi korelasi di antara variabel bebas, karena jika hal tersebut terjadi maka variabel tersebut tidak ortogonal atau terjadi kemiripan. Terjadinya multikolinearitas akan menimbulkan estimasi unik dari setiap variabel tidak muncul. Sehingga tidak dapat menarik kesimpulan dari hasil pengujian hipotesis. Pengujian ada tidaknya multikolinearitas dapat dilakukan dengan melihat nilai koefisien korelasinya. Untuk bisa dikatakan tidak ada multikolenieritas nilai koefisien korelasinya kurang dari 10 .

c) Uji Autokorelasi

Secara sederhana autokorelasi adalah keadaan dimana variabel gangguan pada periode tertentu berkorelasi dengan variabel gangguan pada periode lain. Untuk menguji ada tidaknya autokorelasi tersebut biasanya digunakan uji DurbinWatson.

Gambar 1

Uji Durbin-Waston

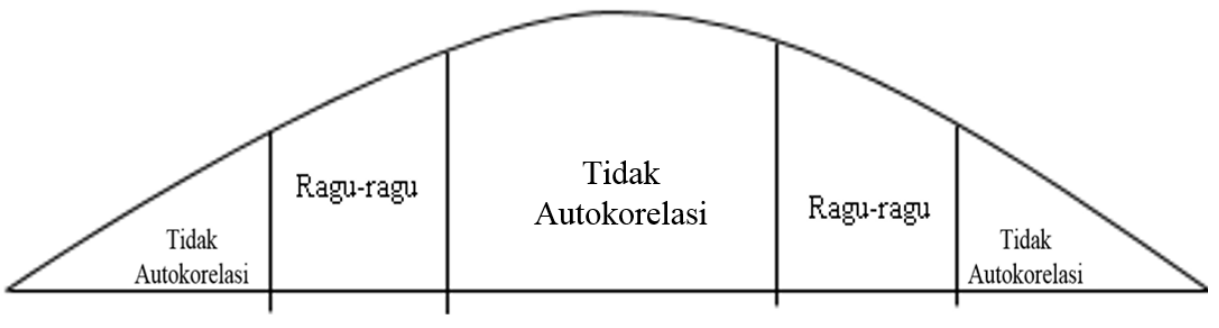

dl

du

$4-\mathrm{du} \quad 4-\mathrm{dl}$

Dalam uji DW diperoleh dua nilai kritis sebagai batasan yaitu $\mathrm{dL}$ batas bawah dan dU batas atas. Sehingga dapat diperoleh suatu aturan dalam menentukan diterima atau ditolaknya hipotesis nol sebagai berikut:

- Jika $0<\mathrm{d}<\mathrm{dL}$, berarti ada autokorelasi positif.

- Jika $\mathrm{dL} \leq \mathrm{d} \leq \mathrm{dU}$, berarti tidak bisa mengambil keputusan apapun.

- Jika $4-\mathrm{dL}<\mathrm{d}<4$, berarti ada autokorelasi yang negatif.

- Jika $4-\mathrm{dU} \leq \mathrm{d} \leq 4-\mathrm{dL}$, berarti tidak bisa mengambil keputusan apapun.

- Jika $\mathrm{dU}<\mathrm{d}<4-\mathrm{dU}$, berarti tidak ada autokorelasi negatif maupun positif. 
d) Uji Heterosdastisitas

Uji heteroskedastisitas bertujuan untuk menguji apakah dalam model regresi terjadi ketidaksamaan varians dari residual satu pengamatan ke pengamatan yang lain. Uji white dilakukan dengan meregresikan residual kuadrat sebagai residual dependen dengan ditambah dengan kuadrat variabel independen, kemudian ditambah lagi dengan perkalian dua variabel independen. Prosedur pengujian dilakukan dengan hipotesis sebagai berikut :

Jika $\alpha=5 \%$, maka tolak $\mathrm{H}_{0}$ jika obs*R-square $>X^{2}$ atau $P$-value $<\alpha$.

Atau dengan menggunakan analisis grafik scatterplot. Pada pengujian scatterplot, pedoman yang digunakan untuk pengambilan keputusan ada tidaknya heteroskedastisitas adalah sebagai berikut:

- Jika ada pola tertentu, seperti titik-titik yang ada membentuk pola tertentu yang teratur (bergelombang, melebar kemudian menyempit), maka mengindikasikan telah terjadi heteroskedastisitas.

- Jika tidak ada pola yang jelas serta titik-titik menyebar di atas dan di bawah angka 0 pada sumbu $Y$, maka tidak terjadi heteroskedastisitas.

c. Moderated Multiple Regretion (MMR)

Variabel moderator $M$ adalah variabel yang mengubah kekuatan hubungan kausal. Kebanyakan analisis moderator mengukur hubungan kausal antara $X$ dan $Y$ dengan menggunakan koefisien regresi. Meskipun klasik, moderasi menyiratkan melemahnya efek kausal, moderator dapat memperkuat atau bahkan membalikkan efek tersebut. Moderasi lengkap akan terjadi dalam kasus di mana efek kausal dari $\mathrm{X}$ pada $\mathrm{Y}$ akan pergi ke nol ketika $M$ mengambil nilai tertentu. Bagian penting dari moderasi adalah pengukuran $X$ untuk hubungan kausal $Y$ untuk nilai yang berbeda dari $M$. Pengukuran Moderasi umumnya, efek moderator ditunjukkan oleh interaksi $X$ dan $M$ dalam menjelaskan $\mathrm{Y}$. Persamaan regresi berganda berikut diperkirakan:

\section{$\mathrm{Y}=\mathrm{i}+\mathrm{aX}+\mathrm{bM}+\mathrm{CXM}+\mathrm{E}(1)$}

Interaksi $X$ dan $M$ atau koefisien $\mathrm{c}$ mengukur efek moderasi. Perhatikan jalan bahwa langkah-langkah yang efek sederhana dari $X$, kadang-kadang disebut efek utama dari $X$, ketika $M$ sama dengan nol. Seperti yang akan terlihat, uji moderasi tidak selalu dioperasionalkan oleh XM jangka produk. Mengingat Persamaan 1, pengaruh X terhadap $\mathrm{Y}$ adalah $+\mathrm{CM}$. Dengan demikian, efek dari $\mathrm{X}$ pada $\mathrm{Y}$ tergantung pada nilai $\mathrm{M}$. Perlu dicatat bahwa efek dari $X$ pada $Y$ sama dengan nol ketika $M$ sama dengan -a / c, yang mungkin atau mungkin tidak menjadi nilai yang masuk akal dari $\mathrm{M}$.

Untuk menguji keberadaan $\mathrm{M}$ apakah benar sebagai pure moderator, quasi moderator atau bukan variabel moderating sama sekali, dapat diamati dengan kriteria sebagai berikut :

- Pure moderator, apabila pengaruh dari $M$ terhadap $Y$ pada output pertama dan pengaruh interaksi $M * X_{1}$ pada output kedua, salah satu signifikannya. Hasilnya pure moderator.

- Quasi moderator, apabila pengaruh dari M terhadap $\mathrm{Y}$ pada output pertama dan pengaruh interaksi $M * X_{1}$ pada output kedua-duanya signifikan. 
- Bukan moderator, apabila pengaruh M terhadap Y pada output pertama dan pengaruh interaksi $M * X_{1}$ pada output kedua, tidak ada satupun yang signifikan.

d. Pengujian Hipotesis

Pengujian hipotesis dengan regresi berganda yang melibatkan variabel moderating dapat dilakukan dengan tiga cara yaitu uji interaksi, uji selisih mutlak, dan uji residual. Uji residual dipilih apabila data yang akan diuji mengalami masalah multikolinearitas, sehingga tidak dapat dilakukan analisis regresi. Sedangkan untuk pengujian pada hubungan langsung menggunakan analisis regresi linier berganda.

a) Analisis Regresi Berganda

Analisis regresi bertujuan untuk mengukur kekuatan hubungan antara dua variabel atau lebih. Hubungan yang dimaksud adalah ketergantungan variabel dependen dengan satu atau lebih variabel independen. Selain untuk mengetahui hubungan antar variabel, analisis regresi juga menunjukan arah hubungan antara variabel dependen dengan variabel independen. Model regresi yang digunakan untuk menguji pengaruh variabel independen terhadap variabel dependen dalam penelitian ini (hipotesis 1-5), adalah:

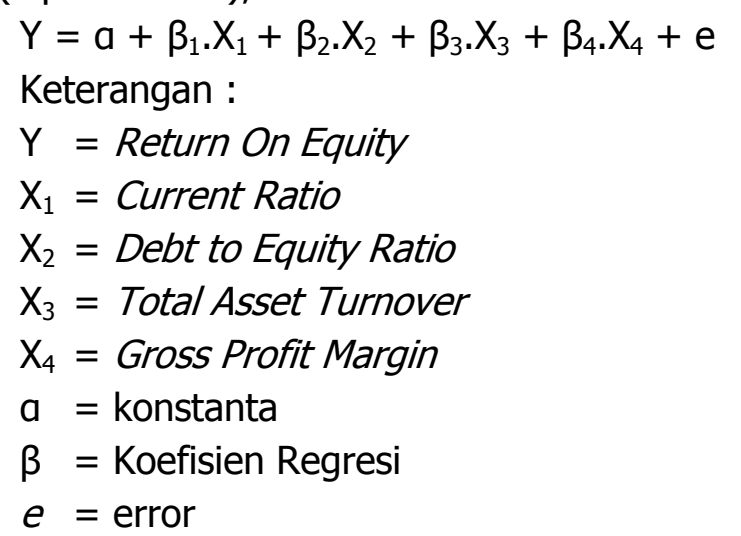

Untuk mengetahui apakah model regresi benar-benar menunjukkan hubungan yang signifikan dan representatif, maka model tersebut harus memenuhi uji asumsi klasik regresi. Besarnya konstanta tercemin dalam dan besarnya koefisien regresi dari masing-masing variabel independen ditunjukkan dengan $X_{1}, X_{2}, X_{3}$, dan $X_{4}$. Analisis regresi dilakukan untuk mengetahui seberapa besar hubungan antara variabel independen dan dependennya. Analisis regresi linier berganda meliputi uji signifikansi parsial (uji t), uji simultan (uji F) dan, Koefesien Determinasi (Adj. $R^{2}$ ).

b) Uji Signifikan Parsial (Uji T)

Pengujian ini pada dasarnya bertujuan untuk menguji pengaruh masingmasing variabel independen secara individu terhadap variabel dependen. Hipotesis nol yang hendak diuji adalah apakah suatu parameter sama dengan nol. Hipotesis alternatifnya adalah apakah parameter suatu variabel tidak sama dengan nol. Tahaptahap pengujiannya adalah sebagai berikut:

- Merumuskan hipotesis

- Menentukan tingkat signifikansi yaitu 0,05 atau $5 \%$

- Menentukan keputusan dengan membandingkan $\mathrm{t}$ hitung dengan $\mathrm{t}$ tabel dengan kriteria sebagai berikut:

* Jika tingkat signifikansi $<0,05$ dan nilai t hitung $>$ t tabel, maka Ho ditolak 
* Jika tingkat signifikansi $>0,05$ dan nilai $\mathrm{t}$ hitung $<\mathrm{t}$ tabel, maka Ho diterima.

c) Uji Simultan (Uji F)

Uji F dimaksudkan untuk menguji model regresi atas pengaruh seluruh variabel bebas secara simultan terhadap variabel terikat (Ghozali, 2011). Dengan kata lain, uji F melihat pengaruh seluruh variabel bebas terhadap variabel terikatnya. Dengan taraf signifikansi sebesar $5 \%$ atau 0,05 dapat ditarik kesimpulan dengan kriteria sebgai berikut:

- Jika nilai $F_{\text {hitung }}<F_{\text {tabel, }}$ maka $\mathrm{HO}$ ditolak dan Ha diterima

- Jika nilai $F_{\text {hitung }}>F_{\text {tabel, }}$ maka $\mathrm{HO}$ diterima dan Ha ditolak

d) Koefisien Determinasi $\left(R^{2}\right)$

Koefisien determinasi merupakan ukuran untuk mengetahui kesesuaian atau ketepatan antara nilai dugaan atau garis regresi dengan data sampel. Jika semua data observasi terletak pada garis regresi akan diperoleh garis regresi yang sesuai atau sempurna, namun apabila data observasi tersebar jauh dari nilai dugaan atau garis regresinya, maka nilai dugaannya menjadi kurang sesuai (Suharyadi, 2004). Koefisien determinasi mengukur seberapa jauh kemampuan model dalam menerangkan variasi variabel dependent (Ghozali, 2011). Nilai $R^{2}$ berkisar antara $0-1$, nilai $R^{2}$ yang lebih kecil atau mendekati nol berarti kemampuan variabel-variabel independent dalam menjelaskan variabel dependent sangat terbatas. Sebaliknya jika nilai $\mathrm{R}^{2}$ lebih besar atau mendekati 1 , maka variabel variabel independent menjelaskan hampir seluruh informasi mengenai variabel dependent.

\section{HASIL DAN PEMBAHASAN}

\section{Hasil Penelitian}

Dari seluruh perusahaan yang go public dan terdaftar di BEI tidak semua dijadikan sampel penelitian. Karena dalam penelitian ini yang dijadikan sampel adalah perusahaan pertambangan Batubara dan MIGAS yang listed dari tahun 2011-2014 yang mengeluarkan data-data keuangan perusahaan indeks (ICMD) dan data yang menghasilkan laba positif selama periode pengamatan (2011-2014). Teknik pengolahan yang digunakan adalah proprosiv sampling sehingga hanya 2 sub sektor pertambangan yang diambil pada penelitian ini. dan hanya 12 perusahaan yang memenuhi syarat penelitian untuk dijadikan sampel.

a. Statistik Deskriptif

Berdasarkan data yang diinput dari ICMD 2015 maka dapat dihitung rasio-rasio keuangan yang digunakan dalam penelitian ini meliputi Return On Equity, Current Ratio, Debt Equity Ratio, Total Asset Trunover, Gross Profit Margin. Dari data mentah yang telah diinput dapat dilihat nilai maksimum, minimum, mean dan standar deviation dari masing-masing variabel penelitian pada tabel V.1 sebagai berikut :

Tabel 5. Descriptive Statistics

\begin{tabular}{llllll}
\hline & $\mathrm{N}$ & Minimum & Maximum & Mean & Std. Deviation \\
\hline$C R$ & 48 & 59,03 & 542,03 & 201,651 & 112,79020 \\
DER & 48 &, 17 & 3,94 & 1,1994 &, 98466
\end{tabular}




\begin{tabular}{llllll} 
TATO & 48 &, 12 & 2,18 & 1,0119 &, 58365 \\
GPM & 48 & 12,14 & 66,89 & 30,0685 & 11,53437 \\
ROE & 48 &, 72 & 190,46 & 21,8638 & 29,87951 \\
NPM & 48 &, 55 & 42,72 & 10,6850 & 9,04540 \\
Valid N & 48 & & & & \\
(listwise) & & & & & \\
\hline
\end{tabular}

Sumber : Output SPSS versi 15, diolah oleh peneliti

Berdasarkan tabel diatas dapat dilihat bahwa ada 48 data dari 4 variabel independen (Current Ratio, Debt Equity Ratio, Total Asset TrunOver, Gross Profit Margin). Pada variabel Current Ratio rata-ratanya 201,6510 dengan standar deviasi 112,79020. Pada variabel Debt Equity Ratio rata-ratanya 1,1994 dengan standar deviasi 0,98466. Pada variabel Total Asset Trunover rata-ratanya 1,0119 dengan standar deviasi 0,58365. Pada variabel Gross Profit Margin rata-ratanya 30,0685 dengan standar deviasi 11,53437. Pada variabel Net Profit Margin rata-ratanya 10,6850 dengan standar deviasi 9,04540. Dan pada Return On Equity (variabel dependen) rata-ratanya 21,8638 dengan standar deviasi 29,87951.

b. Uji Asumsi Klasik

a) Uji Multikolinearitas

Pengujian ada tidaknya multikolinearitas dapat dilakukan dengan melihat nilai koefisien korelasinya. Untuk bisa dikatakan tidak ada multikolenieritas nilai koefesien korelasi < 10. Hasil perhitungan uji multikolinearitas disajikan sebagai berikut :

Tabel 6. Uji Multikolinineritas

\begin{tabular}{lcll}
\hline Variabel & Tolerance & VIF & Keterangan \\
\hline CR & 0,602 & 1,660 & terbebas dari multikolinieritas \\
DER & 0,654 & 1,529 & terbebas dari multikolinieritas \\
TATO & 0,790 & 1,265 terbebas dari multikolinieritas \\
GPM & 0,703 & 1,422 terbebas dari multikolinieritas \\
\hline
\end{tabular}

Sumber : Output SPSS versi 15 , diolah oleh peneliti

Berdasarkan hasil uji multikolineritas di atas, dapat dikesimpulan bahwa untuk nilai VIF Current Ratio sebesar 1,660 kurang dari 10 dimana variabel Current Ratio terbebas dari multikolinieritas. Untuk variabel Debt Equity Ratio nilai VIF sebesar 1,529 kurang dari 10 dimana variabel Debt Equity Ratio terbebas dari multikolinieritas. Untuk variabel Total Asset Trunover nilai VIF sebesar 1,265 kurang dari 10 dimana variabel Total Asset TrunOver terbebas dari multikolinieritas. Dan untuk variabel Gross Profit Margin nilai VIF sebesar 1,422 kurang dari 10 dimana variabel Gross Profit Margin terbebas dari multikolinieritas.

b) Uji Autokorelasi

Untuk menguji keberadaan autokorelasi dalam penelitian ini digunakan uji Durbin-Watson (DW). Hasil pengujian tampak dalam tabel berikut :

Tabel 7. Uji Autokorelasi

\begin{tabular}{cccccc}
\hline Model & $\mathrm{R}$ & $\begin{array}{c}\mathrm{R} \\
\text { square }\end{array}$ & $\begin{array}{c}\text { Adjusted R } \\
\text { Sqaure }\end{array}$ & $\begin{array}{c}\text { Std. Error Of } \\
\text { the Estimate }\end{array}$ & $\begin{array}{c}\text { Durbin- } \\
\text { Waston }\end{array}$ \\
\hline 1 &, 716 & 0,513 & 0,468 & 21,80049 & 1,648 \\
\hline
\end{tabular}


Sumber : Output SPSS versi 15, diolah oleh peneliti

Berdasarkan tabel diatas, diperoleh hasil pengujian ROE menghasilkan DW $=1,648$ yang berada di daerah antara nilai $\mathrm{du}=1,7206$ dan $\mathrm{dl}=1,3619$ sehingga dapat disimpulkan bahwa DW berada di daerah ragu-ragu. Berikut penjelasan gambar dibawah ini :

Gambar 2

Uji Durbin-Watson

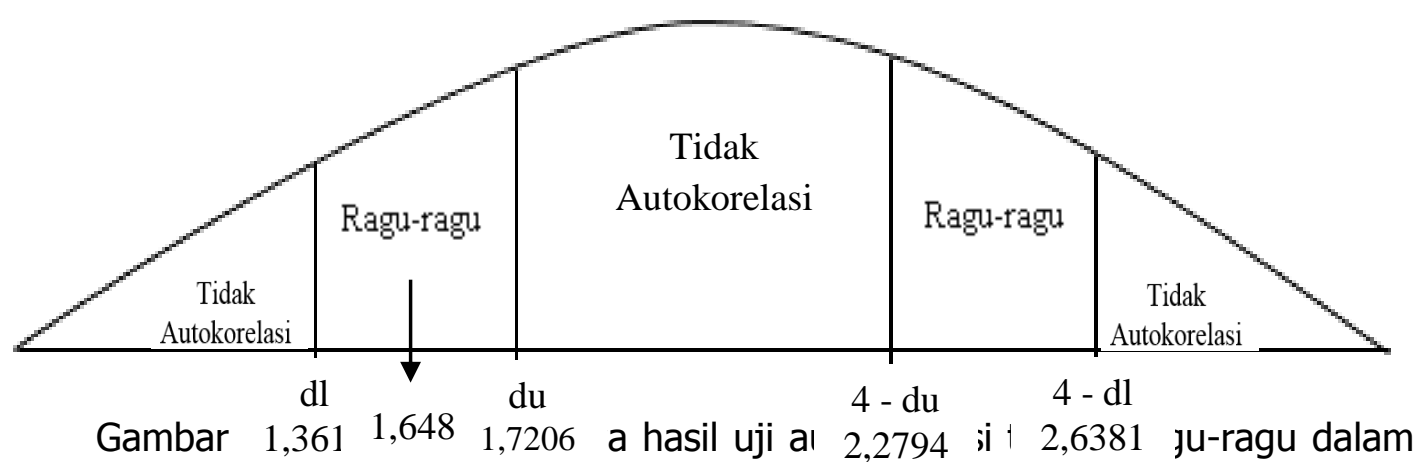
pengambilan keputusan, karena Derdasarkan DVv yaı ıy upeıvıeı ı ısil 1,648 yang terletak antara 1,3619 sampai dengan 1,7206. Jadi dapat disimpulkan bahwa data tersebut tidak bisa untuk mengambil keputusan apapun.

c) Uji Normalitas

Pengambilan keputusan dalam penelitian ini dengan menggunakan statistik model kolmogorov.Smirnov test. Dimana data dikatakan normal apabila nilai Asym.Sig $>0,05$. Adapun hasil dari pengujian normalitas disajikan dalam tabel V.4 sebagai berikut :

Tabel 8. Uji Normalitas

\begin{tabular}{|c|c|c|}
\hline Variabel & Asymp. Sig (2-tailed) & Kesimpulan \\
\hline CR & 0,179 & Normal \\
\hline DER & 0,239 & Normal \\
\hline TATO & 0,756 & Normal \\
\hline GPM & 0,918 & Normal \\
\hline ROE & 0,008 & Normal \\
\hline
\end{tabular}

Sumber : Output SPSS versi 15 , diolah oleh peneliti

Berdasarkan tabel di atas, diketahui bahwa nilai signifikansi Variabel Current Ratio, Debt Equity Ratio, Total Asset TrunOver, dan Gross Profit Margin sebesar $0,179,0,239,0,756$, dan 0,918 . Dimana hasil menujukan tingkat signifikasi diatas 0,05 , hal ini berarti semua variabel yang digunakan terdistribusi normal.

d) Uji Heterokedastisitas

Uji heteroskedastisitas pada penelitian ini menggunakan uji white. Cara pengujiannya adalah dengan meregres residual kuadrat dengan variabel bebas. Kemudian mencari nilai $R^{2}$ untuk menghitung $X^{2}$, dimana $X^{2}=n * R^{2}$. Pengujiannya adalah jika $\mathrm{X}^{2}$ hitung $<\mathrm{X}^{2}$ tabel maka data tersebut tidak ada heterokedastisitas. 
Tabel 9. Hasil uji Heteroskedastisitas

\begin{tabular}{ccccc}
\hline Model & $\mathrm{R}$ & $\begin{array}{c}\mathrm{R} \\
\text { square }\end{array}$ & $\begin{array}{c}\text { Adjusted } \\
\mathrm{R} \text { Sqaure }\end{array}$ & $\begin{array}{c}\text { Std. Error Of } \\
\text { the Estimate }\end{array}$ \\
\hline 1 &, 716 & 0,513 & 0,468 & 21,80049 \\
\hline
\end{tabular}

Sumber : Output SPSS Versi 15, diolah oleh peneliti

Dari tabel V.5 di atas dapat diketahui nilai $\mathrm{R}^{2}$ sebesar 0,513, maka kita dapat mengetahui besarnya $X^{2}$ hitung yaitu $0,513 * 48=24,624$. Sedangkan besarnya $X^{2}$ tabel adalah 9,488 karena $X^{2}$ hitung $<X^{2}$ tabel $(9,488<24,624)$, maka tidak terjadi gejala yang mengandung heterokedastisitas dalam model ini.

c. Analisis Regresi Berganda

Analisis linier berganda ini digunakan untuk mengetahui ada tidaknya pengaruh dari variabel independen. Sehingga dapat diperoleh olah data dan kemudian diterapkan dalam rumus persamaan regresi yaitu $Y=a+b_{1} X_{1}+b_{2} X_{2}+$ $b_{3} X_{3}+b_{4} X_{4}+$ e. Adapun hasil pengolahan data sebagai berikut :

Tabel 10. Analisis Regresi Linier Berganda

\begin{tabular}{lcc}
\hline \multirow{2}{*}{ Variabel } & \multicolumn{2}{c}{ Unstandardized Coefficients } \\
\cline { 2 - 3 } & $\mathrm{B}$ & Std. Error \\
\hline (Constant) & $-61,060$ & 16,471 \\
CR &,- 046 & 0,036 \\
DER & 6,003 & 3,993 \\
TATO & 39,312 & 6,128 \\
GPM & 1,503 & 0,329 \\
\hline Sumber : Output SPSS versi 15, diolah oleh peneliti
\end{tabular}

Berdasarkan tabel di atas dapat diperoleh rumus regresi sebagai berikut : $Y=(-61,060)+(-0,046) X_{1}+6,003 X_{2}+39,312 X_{3}+1,503 X_{4}+e$ Ineterpretasi dari regresi di atas adalah sebagai berikut :

- Nilai kostanta $(A)$ sebesar $(-61,060)$ yang menujukan bahwa ketika nilai variabel independen Current Ratio, Debt Equity, Total Asset Turnover, Gross Profit Margin diasumsikan sebesar nol, maka nilai dari Return On Equity mengalami penurunan sebesar $(-61,060)$.

- Koefisien regresi $X_{1}$ sebesar $(-0,046)$, berarti Current Ratio mengalami penurunan sebesar $1 \%$ maka akan diikuti penurunan Return On Equity sebesar $(-0,046)$ dengan asumsi nilai koefisien variabel independen lainnya tetap atau sama dengan nol.

- Koefisien regresi $X_{2}$ sebesar 6,003, berarti Debt Equity Ratio mengalami kenaikan sebesar 1\% maka akan diikuti kenaikan Return On Equity sebesar 6,003 dengan asumsi nilai koefisien variabel independen lainnya tetap atau sama dengan nol.

- Koefisien regresi $X_{3}$ sebesar 39,312, berarti Total Asset TurnOver mengalami kenaikan sebesar 1\% maka akan diikuti kenaikan Return On Equity sebesar 39,312 dengan asumsi nilai koefisien variabel independen lainnya tetap atau sama dengan nol. 
- Koefisien regresi $\mathrm{X}_{4}$ sebesar 1,503, berarti Gross Profit Margin mengalami kenaikan sebesar 1\% maka akan diikuti kenaikan Return On Equity sebesar 1,503 dengan asumsi nilai koefisien variabel independen lainnya tetap atau sama dengan nol.

d. Uji T (Uji Pengaruh Secara Parsial)

Uji ini digunakan untuk mengetahui apakah variabel independen secara parsial berpengaruh signifikan terhadap variabel dependen. Dimana Return On Equity sebagai variabel dependen dan Current Ratio, Debt Equity Ratio, Total Asset Trunover, Gross Profit Margin sebagai variabel independen sehingga dapat diketahui seberapa besar pengaruh masing-masing variabel yang dihipotesiskan terhadap Retrun On Equity.

Tabel 11. Uji T (Uji Pengaruh Secara Parsial)

\begin{tabular}{cll}
\hline Variabel & $\mathrm{t}$ & sig. \\
\hline CR & $-3,707$ & 0,312 \\
DER & 1,503 & 0,140 \\
TATO & 6,415 & 0,000 \\
GPM & 2,573 & 0,000 \\
\hline
\end{tabular}

Sumber : Output SPSS versi 15, diolah oleh peneliti

Berdasarkan hasil output SPSS seperti yang terlihat pada tabel V.7 hasil perhitungan ada tidaknya pengaruh variabel independen (Current Ratio, Debt Equity Ratio, Total Asset Trunover, Gross Profit Margin) terhadap Return On Equity secara parsial :

- Variabel Current Ratio $\left(\mathrm{X}_{1}\right)$

Nilai $t_{\text {hitung }}$ variabel Current Ratio sebesar $-1,263$ dan $t_{\text {tabel }}$ sebesar 2,015 dengan $a=0,05$ atau 5\%. Dengan demikian $t_{\text {hitung }}<t_{\text {tabel }}(-1,263<2,015)$ dan nilai signifikan sebesar 0,213 lebih besar dari $0,05(0,213>0,05)$ artinya Current Ratio secara parsial tidak berpengaruh dan tidak signifikan terhadap Return On Equity.

- Variablel Debt Equity Ratio $\left(\mathrm{X}_{2}\right)$

Nilai $t_{\text {hitung }}$ variabel Debt Equity Ratio sebesar 1,504 dan $t_{\text {tabel }}$ sebesar 2,015 dengan $a=0,05$ atau $5 \%$. Dengan demikian $t_{\text {hitung }}<t_{\text {tabel }}(1,504<2,015)$ dan nilai signifikan sebesar 0,140 lebih kecil dari 0,05 $(0,140>0,05)$ artinya Debt Equity Ratio secara parsial tidak berpengaruh dan tidak signifikan terhadap Return On Equity.

- Variabel Total Asset Trunover $\left(\mathrm{X}_{3}\right)$

Nilai $t_{\text {hitung }}$ variabel Total Asset TurnOver sebesar 6,415 dan $t_{\text {tabel }}$ sebesar 2,015 dengan $a=0,05$ atau $5 \%$. Dengan demikian $t_{\text {hitung }}>t_{\text {tabel }}(6,415>2,015)$ dan nilai signifikan sebesar 0,000 lebih kecil dari 0,05 $(0,000<0,05)$ artinya Total Asset TurnOver secara parsial berpengaruh dan signifikan terhadap Return On Equity.

- Variabel Gross Profit Margin $\left(\mathrm{X}_{4}\right)$

Nilai $t_{\text {hitung }}$ variabel Gorss Profit Margin sebesar 4,573 dan $t_{\text {tabel }}$ sebesar 2,015 dengan $a=0,05$ atau $5 \%$. Dengan demikian $t_{\text {hitung }}>t_{\text {tabel }}(4,573>2,015)$ dan nilai signifikan sebesar 0,000 lebih kecil dari 0,05 $(0,000<0,05)$ artinya 
Gross Profit Margin secara parsial berpengaruh dan signifikan terhadap Return On Equity.

e. Uji F (Uji Secara Simultan)

Uji F dilakukan untuk menilai pengaruh Current Ratio, Debt Equity Ratio, Total Asset Trunover, dan Gross Profit Margin secara simultan terhadap Return On Equity. Berdasarkan hasil pengolahan data dengan program SPSS versi 15. Maka diperolah hasil sebagai berikut :

Tabel 12. Uji F (Uji Pengaruh Secara Simultan)

\begin{tabular}{lccccc}
\hline Model & Sum of Squares df & Mean Squares & $F$ & Sig. \\
\hline 1 Regression & 21524,660 & 4 & 5381,165 & 11,323 & 0,000 \\
$\quad$ Residual & 20436,243 & 43 & 475,261 & & \\
Total & 41960,903 & 47 & & & \\
\hline
\end{tabular}

Sumber : Output SPSS versi 15 , diolah oleh peneliti

Dari uji annova (analysis of variance) di atas di dapat $\mathrm{F}_{\text {hitung }}$ sebesar 11,323 , sedangkan $F_{\text {tabel }}$ diketahui sebesar 2,584. Dengan tingkat signifikan sebesar 0,000 , dimana sig $<0,05(0,000<0,05)$. Berdasarkan hasil tersebut dapat diketahui bahwa $\mathrm{F}_{\text {hitung }}>\mathrm{F}_{\text {tabel }}(11,323>2,584)$ berarti secara simultan berpengaruh dan signifikasi terhadap Return On Equity.

f. Uji Koefisien Determinasi $\left(R^{2}\right)$

Pengujian ini digunakan untuk mengetahui tingkat ketepatan yang terbaik dalam analisis regresi. Dalam hal ini ditunjukan oleh besarnya koefisien determinasi.

Tabel 13. Uji Koefisien Determinasi

\begin{tabular}{ccccc}
\hline Model & $\mathrm{R}$ & $\mathrm{R}$ Square & $\begin{array}{c}\text { Adjusted } \\
\mathrm{R} \text { Square }\end{array}$ & $\begin{array}{c}\text { Std. Error of } \\
\text { the Estimate }\end{array}$ \\
\hline 1 & 0,716 & 0,513 & 0,468 & 21,80049 \\
\hline
\end{tabular}

Sumber : Output SPSS Versi 15, Diolah Oleh Peneliti

Berdasarkan tabel "model summary", dimana uji ini dapat menggunakan ketentuan $0<\mathrm{R}^{2}<1$. Karena nilai $R$ square diantara $0<0,513<1$. Artinya bahwa kontribusi variabel independen mempengaruhi variabel dependen sebesar 51,3\%, sedangkan sisanya 48,7\% dijelaskan oleh variabel lain diluar model seperti Return On Asset, Debt Asset Ratio, Inventory Turnover, Price Earning Ratio dan Deviden Yield.

g. Uji F (Uji Secara Simultan) Dengan Variabel Moderator

Berikut merupakan hasil olah data uji $F$ (uji secara simultan) dengan variabel moderator :

Tabel 14. Uji F (Uji Secara Simultan) Dengan Variabel Moderator

\begin{tabular}{clccccc}
\hline Model & & Sum of Squares & Df & Mean Square & F & Sig. \\
\hline \multirow{2}{*}{1} & Regression & 18472,309 & 4 & 4618,077 & 8,454 &, 000 \\
& Residual & 23488,593 & 43 & 546,246 & & \\
& Total & 41960,903 & 47 & & & \\
\hline
\end{tabular}


Sumber : Output SPSS Versi 15, Diolah Oleh Peneliti

Berdasarkan hasil olahan data pada tabel V.10 di dapat Tingkat signifikan sebesar 0,000, dengan sig $<0,05(0,000<0,05)$. Sedangkan $F_{\text {hitung }}$ sebesar 8,454 dengan $F_{\text {tabel }}$ diketahui sebesar 2,584. Berdasarkan hasil tersebut dapat diketahui bahwa $F_{\text {hitung }}>F_{\text {tabel }}(8,454>$ 2,584 ) berarti berpengaruh secara simultan dan signifikasi terhadap Return On Equity.

\section{Hasil Pembahasan}

Berdasarkan hasil pengolahan data diatas dapat dibuktikan bahwa :

1. Pengaruh Current Ratio terhadap Return On Equity

Current Ratio merupakan perbandingan antara aktiva lancar dengan hutang lancar. Jika aktiva lancar pada perusahaan sedikit maka, perusahaan akan mengalami kesulitan saat memenuhi hutang lancar pada perusahaan. Berdasarkan hasil pengujian halaman sebelumnya bahwa variabel Current Ratio terhadap Return On Equity tidak berpengaruh dan tidak signifikan terhadap Return On Equity. Hal tersebut bisa dilihat dari kondisi laporan keuangan pada Current Ratio yang tidak stabil atau fluktuatif, bahkan rasio yang dimiliki perusahaan berada di atas ukuran normal (angka 2). Yang membuat Current Ratio menjadi tidak berpengaruh dan tidak signifikan.

Kesimpulan di atas bisa dipahami Current Ratio yang terlalu tinggi menujukan kurang baik, karena hal tersebut menujukan banyak asset perusahaan yang menganggur (aktivitas sedikit) dan yang pada akhirnya dapat mengurangi kemampuan laba perusahaan, sehingga tidak berpengaruh dan tidak signifikan. Dugaan hipotesis diterima, karena Current Ratio tidak berpengaruh dan tidak signifikan terhadap Return On Equity. penelitian ini didukung oleh Machfoedz (1994) dimana Current Ratio berpengaruh terhadap Return On Equity.

2. Pengaruh Debt Equity Ratio terhadap Return On Equity

Debt Equity Ratio merupakan perbandingan antara total hutang dengan modal sendiri. Pada dasarnya memang perusahaan pertambangan membutuhkan hutang dalam jumlah yang tidak sedikit untuk memenuhi kebutuhan dananya. Besar hutang yang ditambahkan ke neraca akan menigkatkan beban bunga. Berdasarkan hasil penelitian pada pengujian halaman sebelumnya bahwa variabel Debt Equity Ratio terhadap Return On Equity mempunyai pengaruh dan tidak signifikan terhadap Return On Equity. Tidak signifikannya Debt Equity Ratio terhadap Return On Equity disebabkan karena ada 1 perusahaan yaitu perusahaan RUIS yang Debt Equity Ratio melebihi angka 2.

Hal ini akan merugikan lebih banyak laba yang tersedia bagi pemegang saham (ROE). Dan bisa dipahami jika biaya yang dipinjam (cost of debt) lebih kecil ini biaya modal sendiri (cost of equity) maka sumber dana dari perusahaan akan efektif dalam menghasilkan laba (menaikan Return On Equity). Semakin tinggi Debt Equity Ratio akan menujukan bahwa komposisi hutang semakin besar dari pada komposisi ekuitas. Dugaan hipotsis ditolak, karena Debt Equity Ratio tidak signifikan terhadap Return On Equity. Penelitian ini didukung oleh Agustina dan Silvia (2012) dimana Debt Equity Ratio berpengaruh dan tidak signifikan terhadap Return On Equity.

3. Pengaruh Total Asset TurnOver terhadap Return On Equity

Total Asset TurnOver merupakan perbandingan antara penjualan dengan total aktiva. Perputaran atau aktivitas yang tinggi pada perusahaan, membuat perusahaan 
akan semakin cepat dalam pengembalian atas investasi yang ditanamkan. Dan semakin efektif tingkat perusahaan dalam penggunaan aktivanya untuk menghasilkan total penjualan bersih. Berdasarkan hasil pengujian halaman sebelumnya bahwa variabel Total Asset TurnOver berpengaruh dan signifikan terhadap Return On Equity.

Hal ini bisa dipahami bahwa dalam mengelolah asset perusahaan mampu menghasilkan kinerja perusahaan yang tinggi yang tercemin dalam perubahan Return On Equity melalui perputarannya sehingga berdampak pada peningkatan tingkat pengembalian (retrun) yang di dapat investor. Dugaan hipotesis diterima, karena Total Asset TurnOver berpengaruh dan signifikan terhadap Return On Equity. Penelitian ini didukung oleh Kwandinata (2005) dan Santosa (2009) dimana Total Asset TurnOver berpengaruh yang signifikan terhadap Return On Equity.

4. Pengaruh Gross Profit Margin terhadap Return On Equity

Gross Profit Margin merupakan perbandingan antara penjualan dikurang harga pokok dengan penjualan. Pengaruh Gross Profit Margin sangat berpengaruh bagi perusahaan untuk mendapatkan laba (Return On Equity). Berdasarkan hasil pengujian halaman sebelumnya bahwa variabel Gross Profit Margin berpengaruh dan signifikan terhadap Return On Equity. Hal ini bisa dipahami bahwa semakin besar Gross Profit Margin maka akan semakin baik keadaan Return On Equity pada suatu perusahaan. Dugaan hipotesis diterima, karena Gross Profit Margin berpengaruh dan signifikan terhadap Return On Equity. Penelitian ini didukung oleh Nurhayati (2015) dan Damayanti (2015) dimana Total Asset TurnOver berpengaruh dan signifikan terhadap Return On Equity.

5. Pengaruh Current Ratio, Debt Equity Ratio, Total Asset TurnOver, dan Gross Proit Margin terhadap Return On Equity dengan Net Profit Margin sebagai moderator

Berdasarkan hasil pengujian halaman sebelumnya bahwa variabel Current Ratio, Debt Equity Ratio, Total Asset TurnOver, dan Gross Profit Margin berpengaruh dan signifikan secara simultan terhadap Return On Equity dengan Net Profit Margin sebagai moderator. Hal tersebut membuktikan bahwa Net Profit Margin berpengaruh dan signifikan dalam memperkuat hubungan antara variabel independen dengan variabel dependen.

\section{KESIMPULAN}

Berdasarkan dari hasil penelitian serta pembahasan peneitian yang telah dilakukan oleh peneliti, maka kesimpulan dari penelitian ini adalah sebagai berikut :

1. Secara parsial variabel Current Ratio tidak berpengaruh dan tidak signifikan terhadap Return On Equity

2. Secara parsial variabel Debt Equity Ratio tidak berpengaruh dan tidak signifikan terhadap Return On Equity.

3. secara parsial variabel Total Asset TurnOver berpengaruh dan signifikan terhadap Return On Equity.

4. Secara parsial variabel Gross Profit Margin berpengaruh dan signifikan terhadap Return On Equity. 
5. Secara simultan Current Ratio, Debt Equity Ratio, Total Asset TurnOver, Gross Profit Margin terhadap Return On Equity berpengaruh dan signifikan, dimana Net Profit Margin sebagai variabel moderator.

\section{DAFTAR PUSTAKA}

Afriyanti Meilinda, dan Moch.chabachib. Pengaruh Faktor Current Ratio, Total Asset Turnover, Debt To Equity Ratio, Sales Dan Size Terhadap Return On Asset (Studi pada Perusahaan Manufaktur Yang Terdaftar di Bursa Efek Indonesia Tahun 2006-2009).

Aminatuzzahra. 2010. Analisis Pengruh Current Ratio, Debt To Equity Ratio, Total Asset Trunover, Net Profit Margin Terhadap ROE. Skripsi. Tidak Dipublikasikan. Semarang : Fe Universitas Diponogoro.

Brighman, Eguene F. 2001. Analisis Laporan Keuangan. Edisi 8, Jakarta : Erlangga.

Hanafi, Abdul. 2004. Akuntansi Keuangan Daerah. Edisi Revisi, Jakarta : Salemba Empat.

Harahap, Sofyan, Syafri. 2007. Analisis Kritis atas Laporan Keuangan, Jakarta: PT Raja Grafindo Persada.

Husnan suad. 1994. Manajemen keuangan (teori dan penerapan keputusan jangka panjang). Edisi Keempat. Yogyakarta : BPFE.

Imam, Ghozali. 2009. Aplikasi multivariate dengan program SPSS, semarang : badan penerbit Universitas Diponogoro.

Juwita, Arimbi. 2009. Prediksi Keuangan Terhadap Kondisi Financial Distress Pada Perusahaan Property Yang Terdaftar Di Bursa Efek Indonesia. Skripsi. Universitas Sebelas Maret.

Kurnia Riza. 2015. Pengaruh Net Profit Margin, Current Ratio, Debt To Equity Dan Total Asset Trunover Terhadap Retrun On Equity Pada Perusahaan Manufaktur Go Public Yang Terdaftar Di Bursa Efek Indonesia Periode 2010-2013. Kediri. Fakultas Ekonomi Universitas Nusantara PGRI Kediri.

Ni'mah Ulin. 2011. Analisis Kinerja Keuangan Pada Koperasi BMT Bina Usaha Kecamatan Bergas Kabupaten Semarang. Skripsi. Tidak dipublikasikan. FE : Universitas Negeri Semarang.

Maryati. 2013. Analisis Pengaruh Rasio Keuangan Untuk Memprediksi Financial Distress Perusahaan (Studi Kasus Pada Perusahaan Maufaktur Yang Terdaftar Di BEI). Skripsi. Universitas Mercubuana Yogyakarta.

Munawir, S. 2002. Akuntansi Keuangan dan Manajemen. Yogyakarta : BPFE

Prastowo, Dwi. 2002. Analisis Laporan Keuangan. Yogyakarta : UPP AMP YKPN 
Purwanti, Yulia. 2005. Analisis Rasio Keuangan Dalam Memprediksi Kondisi Keuangan Financial Distress Perushaaan Yang Terdaftar Di Bursa Efek Jakarta. Skripsi. Universitas Islam Indonesia.

Ramlan, Muhammad. 2013. Analisis Kesulitan Keuangan (Financial Distress) Perusahaan Go Public Pada Bursa Efek Indonesia. Skripsi. Universitas Mulawarman Samarinda

Subramanyam, K.R \& Jhon J. Wild. 2014. Analisis laporan keuangan, jakarta. Penerbit Salemba Empat.

Salim Jihan. 2015. Pengaruh Leverage (Dar, Der, Dan Tier) Terhadap Roe Perusahaan Properti Dan Real Estate Yang Terdaftar Di Bursa Efek Indonesia Tahun 2010 - 2014. Fakultas Ekonomi dan Binis Perbanas Institute

Tandelini, Eduardus. 2001. Analisis Investasi Dan Manajemen Portofolio. Yogyakarta : BPFE

Ni'mah Ulin. 2011. Analisis Kinerja Keuangan Pada Koperasi BMT Bina Usaha Kecamatan Bergas Kabupaten Semarang. Skripsi. Tidak dipublikasikan. FE : Universitas Negeri Semarang.

Yulsiati Henny. 2016. Pengaruh Debt To Assets Ratio, Debt To Equity Ratio Dan Net Profit Margin Terhadap Retrun On Equity Pada Perusahaan Property Dan Real Estate Yang Terdaftar Di Bursa Efek Indonesia. Akuntansi Politeknik Negeri Sriwijaya.

Zulfadli. 2013. Pengaruh Current Ratio, Debt To Equity Ratio, Debt To Asset Ratio, Net Profit Margin, Gross Profit Margin Terhadap Retrun On Equity Pada Perusahaan Pertambangan Batu Bara Dan Minyak Gas Bumi Yang Terdaftar Di Bursa Efek Indonesia Periode 20082011. Skripsi. Tidak Dipublikasikan. Fakultas Ekonomi Universitas Maritim Raja Ali Haji.

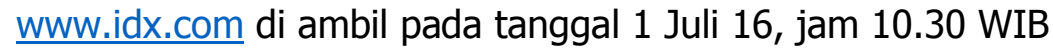

http://www.indonesia-investments.com di ambil pada tanggal 25 November 2016 jam 10:36 WIB

www.wikipedia.id di ambil pada tanggal 8 Desember 2016, jam 08:00 WIB

www.britama.com diambil pada tanggal 24 Desember 2016, jam 09.00 WIB 